\title{
REASSESSING THE LINKS WITH HEALTH AND THE WELFARE STATE
}

\author{
Susan St John*
}

The purpose of this conference is to examine how ACC might evolve to serve us well for the new risks and changed environment of the $21^{\text {st }}$ century. The social contract that underpinned the Accident Compensation Amendment Act 1974 must evolve in response to changed needs if the scheme is to retain its credibility and public support.

Right from the inception of the scheme, a range of horizontal inequities have arisen from the distinction between disability from accident and disability arising from illness. ACC has always stood out like the proverbial sore thumb within the rest of a largely targeted flat-rate welfare state with respect to income replacement provisions. However, income replacement is only one of the issues. This panel will specifically address the sickness/accident boundary where ameliorating the more outstanding anomalies for the long-term disabled is well overdue. In particular, Robert Stephens evaluates the difference in the range of assistance available to the disabled sick versus the accident victim, beyond the obvious difference in their treatment for income replacement. Grant Duncan examines the boundary issues involved in assessing the income replacement for long-term accident victims who may be judged fit for some kind of work even though they can no longer replace their former earning capacity.

Sir Owen Woodhouse believed an integrated sickness/accident scheme was ultimately possible, and the Law Commission's review in 1988 supported this direction. ${ }^{1}$ When Sir Owen went to Australia in the 1970s it was to advise on an integrated scheme. While his recommendations were never adopted in that country and have been largely ignored in New Zealand, evolutionary change has inevitably moved ACC in the direction of recognising more, not fewer, episodes of misfortune as coming within the ACC ambit.

The sickness/accident divide is not the only boundary issue however. Another is the work/nonwork distinction. The changed work environment of the $21^{\text {st }}$ century is very different to the world that saw the introduction of the 1974 Act. With the extension of the free market model and labour

* Senior Lecturer in Economics, University of Auckland.

1 New Zealand Law Commission Personal Injury: Prevention and Recovery (Report on the Accident Compensation Scheme) (NZLC R4, Wellington, 1988). 
contract law, there has been a growth of more casual, more flexible employment. Self-employment and home-based work has become more the norm and low-income earners often have multiple jobs. As the world has become more mobile, there are more workers travelling extensively for workrelated duties, such as conferences and consultancies and more of them working from home. In this brave new world of work, the distinction between what is a work accident and what is a non-work accident is ever harder to maintain.

While earners can expect the same ACC treatment whether their accident is work or non-work related it has been necessary however to maintain the distinction for both the operation of the partnership scheme and the differential levy system. In 2000, the experiment to privatise the employer account was abandoned and there was a return to the State as monopoly provider. ${ }^{2}$ However, under the partnership scheme, private sector involvement remained in the form of employer self-insurance.

In this scheme, the employer pays for the costs of work accidents of fixed duration, or for up to a 'stop loss' amount. The purpose is to create an incentive for improved safety for employees and for speedy rehabilitation of injured workers. There is an obvious incentive to make sure that non-work accidents are not classified as work accidents as the employer expects to pay only for work accidents. An unintended side effect however may be of little surprise. There is emerging evidence that work-related injuries are being passed off as non-work injuries with increasing disputes in the employment courts. One of the important tasks to be undertaken is a full assessment of the partnership scheme to see whether the hoped for results in safety outcomes justify the difficulties of maintaining the work/non-work distinction.

The other use for the non-work/work boundary is for the setting of the employer levy rates. Since the inception, differential levies have been used to reflect different industrial risk, and in 1992 there was a clear separation of the financing of work accidents, largely to align the scheme with the needs of private insurance for the employer account. The fiction that accidents are the direct and sole responsibility of the place of employment where they occur led to experiments with experience rating. This sent ACC down the wrong path to look for accident prevention and rehabilitation incentives.

The original Woodhouse vision was that the needs of workers did not vary because the accident occurred out of work rather than at work. Moreover, industries were inter-connected and work accidents were not neatly attributable to just one activity. Reflecting this, he recommended a flat

2 Accident Insurance (Transitional Provisions) Act 2000. 
levy paid at the same rate by all employers to cover all accidents. ${ }^{3}$ The case for a flat levy was made again later by the Law Commission in its 1988 report. ${ }^{4}$

We have come a long way from believing that differential levies have something to with safety incentives and now safety incentives are imposed by alternative means, yet differential levies with all their complexities remain. The distinction between different industries' risk is going to become much more difficult to maintain in the environment of the $21^{\text {st }}$ century and has always been irrelevant for the self-employed. Consider the chemical sensitivity syndrome for example. Is there really a valid distinction between the work and out of work impacts of chemicals? The manufacture of the chemicals may be safe and low levies paid, but the effect of the chemicals in use may be devastating. Why should the industry be classified as low-risk on the basis of the production process alone? Then there are the problematic 'on the way to work' accidents. Currently the definition of a work accident includes the 'on the way to work' accidents but only where the employer has supplied the vehicle. ${ }^{5}$

The boundaries between paid work and non-paid work in the home are also bound to raise more issues. This issue particularly affects women who take time out to have children. For example, one of the policies floated in some quarters involves income splitting. If this splitting is actual rather than notional as the advocates appear to be demanding, there are implications for her work conditions including ACC levies and income replacement coverage.

Perhaps far more than in the 1960s, the thinking has to be holistic. Back then, clear demarcations between what was covered in the scheme and what was excluded were more possible. There were clearer boundaries between accident and sickness, compensation for accidents and compensation for just generally being out of a job. With the growth in unemployment it has been hard to distinguish between the latter two. It may be that income replacement has to move more in the direction of providing a basic income regardless of cause of disability or unemployment. We have a prototype of this in the New Zealand superannuation scheme.

This is a vast topic and the panel can at best scratch the surface. Economist Nicholas Barr points out that the need for social insurance mechanisms provided by the welfare state in the $21^{\text {st }}$ century are going to become more not less necessary. ${ }^{6}$ It seems very important for us to be clear about the

3 New Zealand Royal Commission of Inquiry into Compensation for Personal Injury Compensation for Personal Injury in New Zealand: Report of the Royal Commission of Inquiry (Government Printer, Wellington, 1967) para 336.

4 New Zealand Law Commission, above n 1.

5 Injury Prevention, Rehabilitation, and Compensation Act 2001, s 28(1)(c).

6 Nicholas Barr The Welfare State as Piggy Bank: Information, Risk, Uncertainty, and the Role of the State (Oxford University Press, New York, 2001). 
nature of the social contract in ACC and to convey the advantages of this approach. The attack on the basic tenets of ACC in the late 1990s is proof indeed that we cannot be too complacent.

Like Barr, I do not see the welfare state withering away - but the need for it, and its social insurance aspects, becoming even more crucial in light of new complex risks. For example, the implications of gene technology are that it might allow wide discrimination and result in less risk sharing in private health insurance. Along with this, problems are raised by the ageing of the population and the uncertainties of the inexorable gains in longevity and the uninsurable costs of long-term care. I think it will be important to think outside the circle once again to redefine social insurance and the place of ACC within it. This session begins the process. 